\title{
Chitra Disinfection Gateway for the Management of COVID 19 in Public Entry Places
}

\author{
Jithin Krishnan ${ }^{1}$ - N. N. Subhash ${ }^{1}$. C. V. Muraleedharan ${ }^{1}$ - P. V. Mohanan ${ }^{1} \cdot$ Maya Nandakumar $^{1} \cdot$ S. Neethu ${ }^{1}$. \\ R. Rethnagireeshwar ${ }^{1}$
}

Received: 11 May 2020 / Revised: 19 June 2020 / Accepted: 25 June 2020 / Published online: 4 July 2020

(c) Indian National Academy of Engineering 2020

\begin{abstract}
Chitra Disinfection Gateway is meant for the decontamination of personnel entering a cleaner private space from a public space. This is equipped with an arrangement for generating hydrogen peroxide mist and ultraviolet rays. Hydrogen peroxide mist will decontaminate clothes, hands and the bags a person carries. The ultraviolet system will decontaminate the chamber once the person has moved out. The system is controlled electronically by sensors and actuators. The sensors fixed in the chamber detect the entry of a person and initiates the hydrogen peroxide atomization process. The person is required to walk through the chamber. When the person exits the chamber, the system will put off the hydrogen peroxide atomization system and will turn on the UV lamp inside the chamber to decontaminate it. The ultraviolet system will be ON for a predefined time and after the process, the next person can enter the walkway. The whole process takes a maximum of $40 \mathrm{~s}$. The safety and efficacy of the system have been validated experimentally through both in vivo and in vitro studies.
\end{abstract}

Keywords Hydrogen peroxide mist · Disinfection · Ultraviolet disinfection

\section{Introduction}

It is understood that SARS-CoV-2 is a respiratory virus and it is mainly transmitted between people through "respiratory droplets" when symptomatic people sneeze or cough (Rothan and Biareddy 2020). But like influenza, this virus appears to spread both through large droplets and droplets smaller than five micrometers (aerosols) that infected people might release, especially while coughing. Through these aerosols, one's dress and shoes as well as the article one carries get contaminated during exposure in public places. If the virus is already on one's body or clothes, it is likely to pass on to other surfaces which come in contact. Other people might touch these surfaces accidentally. So, any form of eliminating such kind of transfers should be welcomed.

There has been a section of health experts and epidemiologists who advocate herd immunity as a possible solution to coronavirus pandemic (Kwok et al. 2020). Vaccine,

Jithin Krishnan

jithinkrishnan@sctimst.ac.in

1 Biomedical Technology Wing, Sree Chitra Tirunal Institute for Medical Sciences and Technology, Trivandrum 695012, India more when than if found, will bring the same effect on the population. Since most patients of COVID-19 are either asymptomatic or have mild illness, health economy strategists have been of the view that herd immunity combined with targeted medical care of serious patients is the best way to deal with coronavirus pandemic. Preparing for herd immunity involves the controlled exposure of the population to the disease, with control over the extent of exposure to the viral load. This calls for all efforts towards bringing down the level of bioburden one gets exposed to so that the exposure becomes subclinical.

It was in this background, along with many other proposals to address the COVID-19 management by providing solutions which are easily replicated across the country using locally available resources, a disinfection gateway for reducing the viral load from people entering public places was proposed and developed.

\section{Methodology}

Chitra Disinfection Gateway is built as a walkthrough which can be installed in public places and passages. The structure is $4 \mathrm{~m} \times 1.5 \mathrm{~m} \times 2 \mathrm{~m}$ in dimension (Fig. 1). There are 


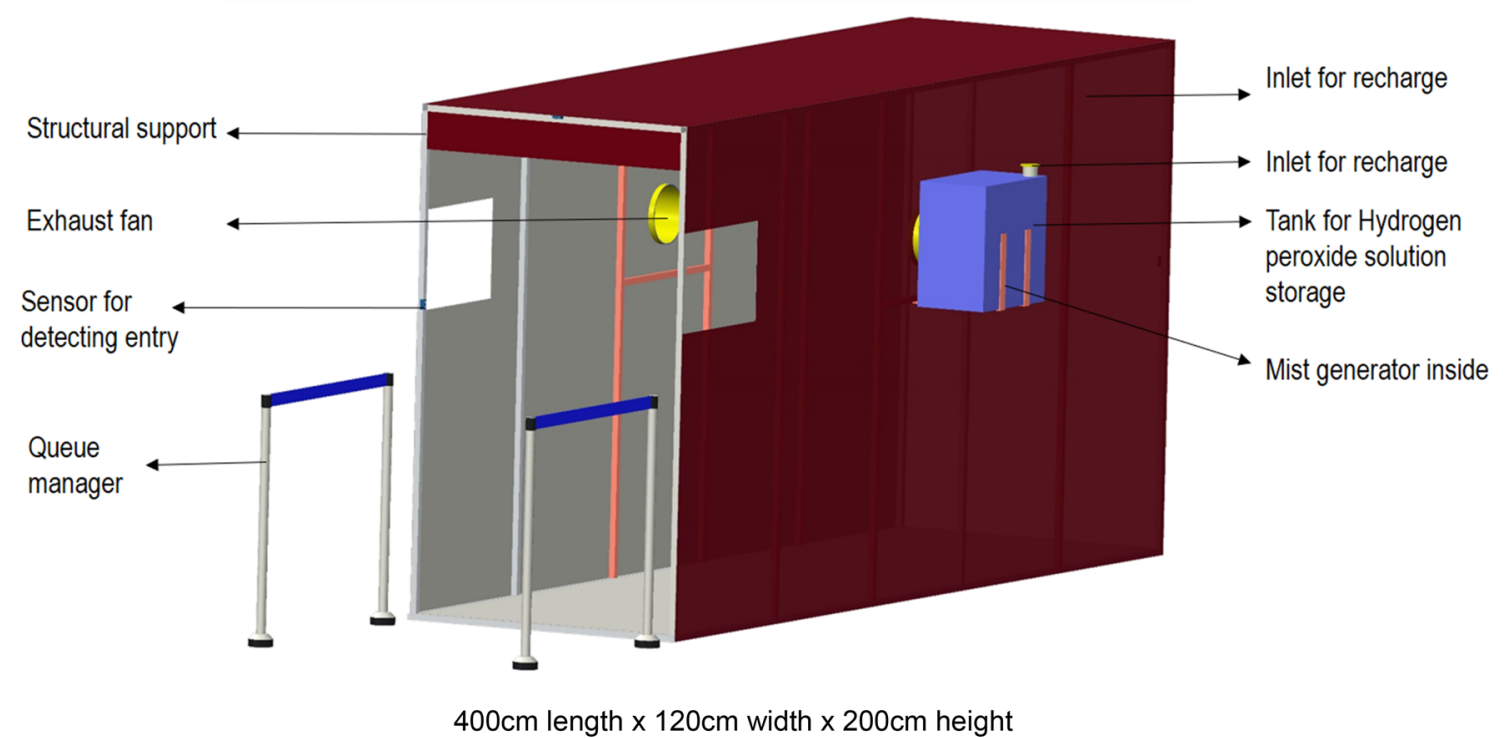

Fig. 1 Assembly diagram of the disinfection gateway

two tanks which are fitted on either side of the chamber which contain the hydrogen peroxide mix for the disinfection process. There are two outlets inside the chamber through which atomized hydrogen peroxide is being blown in from the side tanks. The atomization process is done using ultrasonic vibrators which convert the liquid in the tanks to very fine atomized mist with a droplet size of 2-10 microm diameter and this mist is being blown inside the chamber using blower fans. Along with the mist generator, a set of UV lamps are used for disinfection of the system. UV type C sources are well proven for microbial disinfection. The UV lamp is meant for bioburden reduction inside the chamber after each passage of a person.

Figure 2 shows the system level and component level breakup of the disinfection gateway.

The control console provided has sensors for detecting the entry and exit of a person and a microcontroller which coordinates the timing sequences and the mist generation process. There are indicators placed at the entry, one red and one green, which tell the person in the queue whether he can enter or not. Once the green light in the front of the gateway is $\mathrm{ON}$ a person can enter and he needs to be inside the chamber till the green light inside the chamber is ON. After the exit, which is sensed by the exit sensor, the UV lamp is switched $\mathrm{ON}$ for a predefined time.

The UV ray is used only for disinfecting the gateway, when there are no people inside the gateway and hence does not pose any health or safety hazard. Occupational Health and Safety Officials (OSHA) had provided guidance for ultraviolet radiation exposure (Institute and for Occupational Safety and Health 1972). Overexposure to UVC may lead to photo-conjunctivitis and skin irritation. So, eye and skin exposure time limits the practical usage of ultraviolet germicidal irradiation during human occupancy of design spaces. The threshold limit value (TLV) recommended by the American Conference of Governmental Industrial Hygienists (ACGIH) for $253.7 \mathrm{~nm} \mathrm{UVC}$ is $6 \mathrm{~mJ} / \mathrm{cm}^{2}$ for any 8-h period.

The risk mitigation strategies adopted during the UVC disinfection during gateway design were.

1. The TLV values must be less than $6 \mathrm{~mJ} / \mathrm{cm} 2$ for an $8-\mathrm{h}$ period. First, the system was designed in such a way that there is no direct exposure of human beings to UVC. The UVC light is switched ON only if the IR/ultrasonic sensors detect that there is no human being inside. Second, the time of operation of UVC light is 10 seconds or lesser. Hence, a sufficient safety margin is provided.

2. It should be noted that UVC germicidal process is effective at the line of sight. Sufficient shielding has been provided by the walls of the gateway to ensure that there is no UVC leakage in the line of sight.

3. A warning message has been provided on the device, as a part of the risk management plan and instructions for use: Exposure to germicidal UVC can cause injury to the eyes and skin.

\section{Efficacy of Hydrogen Peroxide as a Disinfectant}

Chitra Disinfection Gateway employs $0.5 \%$ hydrogen peroxide solution to generate mist using an ultrasonic atomizer. As per the Centre for Disease Control (CDC), USA guidelines 


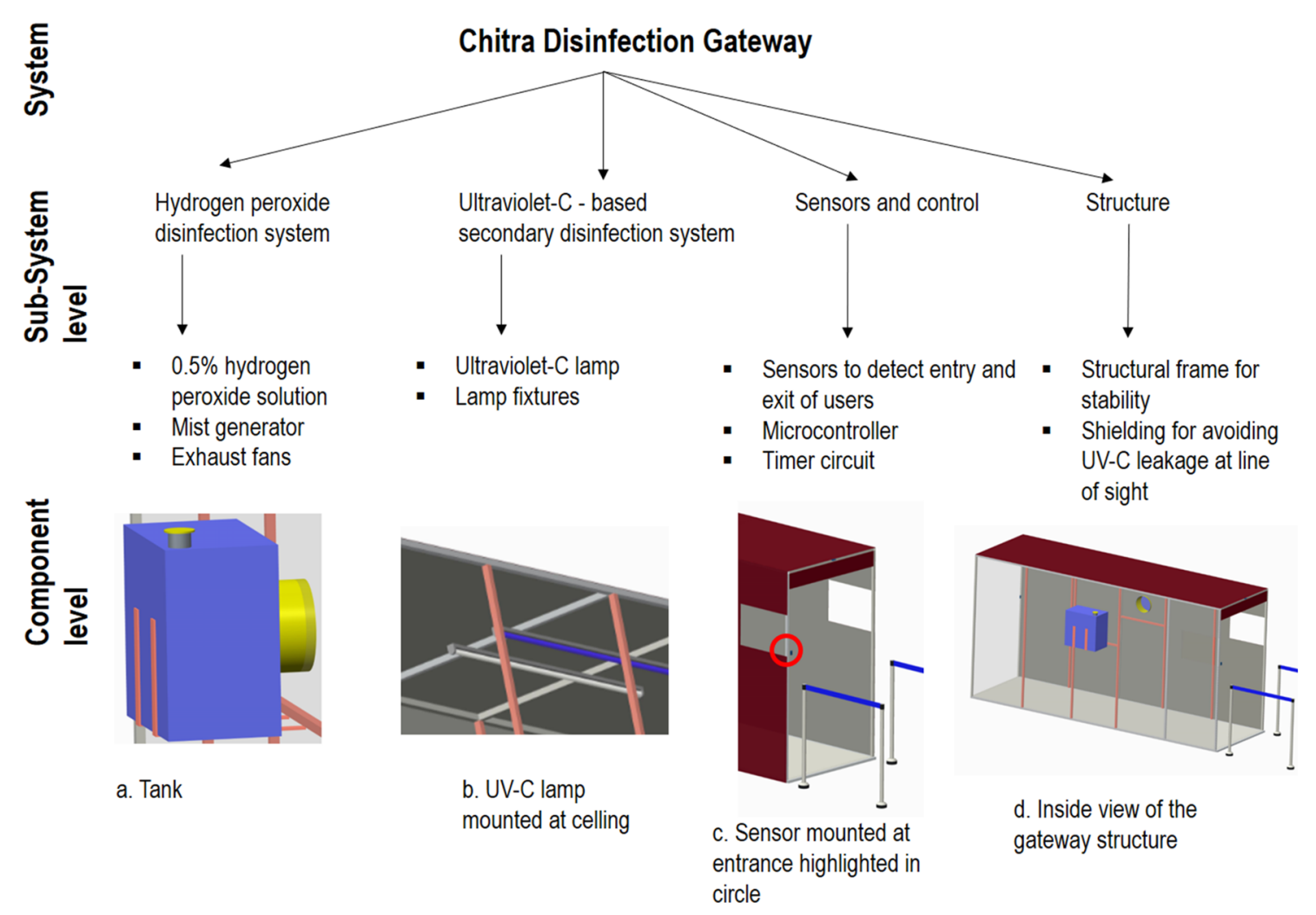

Fig. 2 Detailed view of the components of the disinfection gateway

(Centers for disease control and prevention 2002), this concentration of hydrogen peroxide has demonstrated bactericidal and virucidal activity in $1 \mathrm{~min}$ and mycobactericidal and fungicidal activities in $5 \mathrm{~min}$. Viruses are more fragile and unstable than bacteria and are easier to destroy. The hydrogen peroxide mist from the Chitra Disinfection Gateway gets deposited on the clothing when one person walks through it. The droplet size of atomized hydrogen peroxide is in the range of 2-10 microns. In this size, the droplets from the mist will deposit over the person's clothes and body in the process of walking through the gateway, and subsequently, the disinfection happens. Since the droplet size is too small, the person will not have the feeling of being drenched. Within the next few minutes, this mist reduces the virus load from the surface of the clothing, even after he has moved out of the gateway.

There is ample scientific evidence to the fact that this type of disinfection process provides 3-4 log reduction (reduction by 1000-10,000-fold) of the viruses (Pottage et al. 2010; Tuladhar et al. 2012).

\section{Safety Considerations of Hydrogen Peroxide}

Hydrogen peroxide (at $3 \%$ concentration) is a mild disinfectant used on the skin to prevent infection of minor cuts, scrapes, and burns. It may also be used as a mouth rinse to help remove mucus or to relieve minor mouth irritation (e.g., due to canker/cold sores, gingivitis). Hydrogen peroxide breaks down into water and oxygen, and does not have any environmental issues.

As per the guidelines of the Occupational Safety and Health Administration (OSHA 1992), USA, the safe Time Weighted Average (TWA) concentration of hydrogen peroxide in air is $1.4 \mathrm{mg} / \mathrm{m}^{3}$ of air (which corresponds to $1 \mathrm{ppm}$ ) for an 8-h shift duration (The National Institute for Occupational Safety and Health 1994). In the case of Chitra Disinfection Gateway, the exposure duration is between 5 and $10 \mathrm{~s}$ and the concentration of hydrogen peroxide in the zone is $1.5 \mathrm{ppm}\left(2.1 \mathrm{mg} / \mathrm{m}^{3}\right)$. 
As per the pocket guide on chemical hazards for hydrogen peroxide published by National Institute for Occupational Safety and Health (NIOSH), the safe inhalation limit is $75 \mathrm{ppm}$ and the Chitra Disinfection Gateway has $1.5 \mathrm{ppm}$ design limits, providing a very good safety margin (The National Institute for Occupational Safety and Health 1973).

\section{Hydrogen Peroxide vs. Other Disinfectants}

Disinfectants are created with one purpose: to kill microbes and pathogens. In other words, by definition, disinfectants are destructive to cells, which means none are completely harmless. However, some active ingredients are safer for human health and the environment than others. The most widely used active ingredients in disinfectants include sodium hypochlorite (bleaching powder), quaternary ammonium compounds (QAC) and hydrogen peroxide. A comparison of the basic safety and efficacy of these basic ingredients is provided in (Table 1) (Neighbour and Newberry 1994).

\section{Experimental Validation}

Though the safety and efficacy of hydrogen peroxide are well established, the Institute chose to confirm the suitability of the materials through a series of safety and efficacy studies. These studies were carried out in laboratories practicing quality management systems conforming to ISO/IEC 17,025:2017-General requirements for the competence of testing and calibration laboratories and accredited by the Le Comité Français d'Accréditation (COFRAC), the national accreditation agency of France. The following studies were planned as part of the experimental validation.
- Antimicrobial activity of $0.5 \%$ hydrogen peroxide solution

- Reduction in bioburden levels on clothing of person walking through the gateway

- Reduction in bioburden levels on the hands of person walking through the gateway

- ISO 10,993-10: Biological evaluation of medical devices-Part 10: tests for irritation and skin sensitization

\section{Antimicrobial Activity of Hydrogen Peroxide}

The bactericidal property of $0.5-3 \%$ concentrations of hydrogen peroxide was tested for different exposure time periods. $\mathrm{H}_{2} \mathrm{O}_{2}$ even at $0.5 \%$ concentration and exposure of five minutes was found to be bactericidal for Gram-positive S. aureus ATCC 25923, S. aures ATCC 700698 (MRSA), Gram-negative E. coli ATCC25922 and Pseudomonas aeruginosa ATCC 9027.

\section{Reduction in Bioburden Levels on Clothing of Person Walking Through the Gateway}

100 sq.cm of sterilized shirting material was used in triplicate for the study. The samples were loaded with $10^{6} \mathrm{cfu} /$ $\mathrm{cm}^{2}$ of Bacillus subtilis ATCC 6633. Before and after the exposure of the test material to the Chitra Disinfectant Gateway, the bacterial load was assessed. Before the exposure, the bacterial load recovered was on average $7.3 \times 10^{5} \mathrm{cfu} /$ $\mathrm{cm}^{2}$. After exposure to the disinfectant gateway, no bacteria were recovered from the test samples.

Table 1 Comparison of safety of disinfectants (Neighbour and Newberry (1994))

\begin{tabular}{|c|c|c|c|c|}
\hline S.no & Parameter & $\begin{array}{l}\text { Hydrogen peroxide ( } 3 \% \text { concentra- } \\
\text { tion) }\end{array}$ & $\begin{array}{l}\text { Sodium hypochlorite }(5.25 \% \text { con- } \\
\text { centration) }\end{array}$ & $\begin{array}{l}\text { Quaternary ammonium compounds } \\
\text { (QAC) }\end{array}$ \\
\hline 1 & Effectiveness & $\begin{array}{l}\text { Effective against a broad spectrum } \\
\text { of microbes including H1N1 } \\
\text { (Influenza A), norovirus and } \\
\text { MRSA }\end{array}$ & $\begin{array}{l}\text { Effective against most bacteria and } \\
\text { some viruses including HIV, HBV, } \\
\text { H1N1 (Influenza A), MRSA and } \\
\text { TB }\end{array}$ & $\begin{array}{l}\text { Effective against a broad spectrum } \\
\text { of microbes including MRSA and } \\
\text { H1N1 (Influenza A) }\end{array}$ \\
\hline 2 & EPA toxicity category & Category IV (relatively nontoxic) & Category I (highly toxic) & Category III (slightly toxic) \\
\hline 3 & Dwell time & $1-10 \mathrm{~min}$ & $5-10 \mathrm{~min}$ & $10 \mathrm{~min}$ \\
\hline 4 & Health effects & $\begin{array}{l}\text { Certified by EcoLogo to meet } \\
\text { environmental and human health } \\
\text { criteria }\end{array}$ & $\begin{array}{l}\text { Corrosive to eyes and skin, and a } \\
\text { respiratory irritant; }\end{array}$ & $\begin{array}{l}\text { Can cause contact dermatitis and } \\
\text { nasal irritation }\end{array}$ \\
\hline 5 & Exposure controls & Regular ventilation is adequate & $\begin{array}{l}\text { Personal protection equipment and/ } \\
\text { or increased ventilation should be } \\
\text { used }\end{array}$ & $\begin{array}{l}\text { Personal protection equipment and } \\
\text { proper ventilation should be used }\end{array}$ \\
\hline 6 & Environmental issues & $\begin{array}{l}\text { Certified by EcoLogo to meet } \\
\text { environmental and human health } \\
\text { criteria }\end{array}$ & Toxic to aquatic organisms & Very toxic to aquatic life \\
\hline
\end{tabular}




\section{Reduction in Bioburden Levels on the Arm of Person Walking Through the Gateway}

The microbial load on an individual was assayed before entering the Chitra Disinfection Gateway and after walking through the gateway. One forearm of the personnel was swabbed using swab soaked in physiological saline before entering the gateway, and after entering the gateway, the other arm was swabbed.

The microbial load on the forearm was $16 \mathrm{cfu} / \mathrm{cm}^{2}$ before entering the Chitra Disinfectant Gateway. After passing through the gateway, the bioburden load was reduced to $0.75 \mathrm{cfu} / \mathrm{cm}^{2}$.

\section{ISO 10993-10: Tests for Irritation and Skin Sensitization}

The study was designed to evaluate the animal irritation response of $0.5 \%$ hydrogen peroxide solution intended to be used as a disinfectant in Chitra Disinfectant Gateway. The study was conducted to meet the requirements of ISO 10993-10:2010: Biological evaluation of medical devices-Part 10: test for irritation and skin sensitization (Pottage et al. 2010b; Medina-Cordoba et al. 2018)

The test sample ( $0.5 \%$ hydrogen peroxide) and control (physiological saline) were soaked in absorbent gauze piece and applied topically on the clipped skin of the New Zealand white rabbits. Application sites were covered with occlusive bandage for $4 \mathrm{~h}$. The application sites were observed for any tissue reactions at $1 \mathrm{~h}, 24 \mathrm{~h}, 48 \mathrm{~h}$ and $72 \mathrm{~h}$ after removal of patches. The test material did not produce any irritation following dermal application and confirmed that $0.5 \%$ hydrogen peroxide is non-irritant.

\section{Summary of Tests}

The prime focus of the validation of the disinfection gateway was to prove the safety and efficacy. The safety experiments were carried out in rabbits and the results showed that the concentration of $0.5 \%$ which we are using for mist regeneration does not cause any harm or irritation or sensitization. The tests were in accordance with ISO 10993. The microbiology experiments proved the efficacy of the gateway that it reduces the bioburden load on things that are passing through it. All the experiments proved the disinfection gateway can act as a good tool in COVID management by reducing the bioburden and thereby assisting in the fight against COVID 19 spread.

\section{Conclusions}

From design considerations and based on the experimental validation studies, it can be concluded that the Chitra Disinfection Gateway is designed by taking all precautions of chemical safety aspects and is providing a very good safety margin considering the exposure limits for hydrogen peroxide. Hence, the device does not pose any safety hazards for the people who use it.

The CDG is devised to reduce the viral bioburden a person carries when one enters a private space (which is relatively less contaminated) from a public zone (like streets, public transport, markets, railway stations, bus stations), thereby achieving the control of the bioburden in the private space. These private spaces could be entities like offices, banks, laboratories, and educational institutions,. where a person is likely to spend more time than one spends in public space. This minimizes the risk of communal spread of the disease when the lockdown conditions are getting released.

Acknowledgements The experiments on animals were conducted with appropriate approvals from IAEC (Institute Animal Ethics Committee) which is in line with CPCSEA (Committee for the Purpose of Control And Supervision of Experiments on Animals).

Funding This was funded by Department of Science and Technology, Ministry of Science and Technology, Technical research Centre for Biomedical Devices.

\section{References}

CDC (2002) Centers for disease control and prevention (CDC): chemical disinfectants- guideline for disinfection and sterilization in healthcare facilities. https://www.cdc.gov/infectioncontrol/guide lines/disinfection/disinfectionmethods/chemical.html. Accessed 11 Apr 2020

Kwok KO, Lai F, Wei WI, Yeung S, Wong S, Tang JWT (2020) Herd immunity - estimating the level required to halt the COVID19 epidemics in affected countries. J Infect 80:6. https://doi. org/10.1016/j.jinf.2020.03.027

Medina-Cordoba LK, Valencia-Mosquera LL, Tarazona-diaz GP, del Arias-Palacios JC (2018) Evaluation of the efficacy of a hydrogen peroxide disinfectant. Intern J Pharm Sci ISSN 10(10):0975-1491

Neighbour NK, Newberry LA et al (1994) University of arkansas the effect of microaerosolized hydrogen peroxide on bacterial and viral poultry pathogens. Poult Sci 73:1511-1516

OSHA (1992) Occupational chemical database: US Department of Labour- Entry for hydrogen peroxide. https://www.osha.gov/ chemicaldata/chemResult.html?RecNo=630. Accessed $11 \mathrm{Apr}$ 2020

Pottage T, Richardson C, Parks S, Walker JT, Bennett AM (2010b) Evaluation of hydrogen peroxide gaseousdisinfection systems to decontaminate viruses. J Hosp Infect 74:55-61

Pottage T, Richardson C, Parks S, Walker JT, Bennett AM (2010) Evaluation of hydrogen peroxide gaseous disinfection systems to decontaminate viruses. J Hospit Infect 74:2010 
Rothan HA, Biareddy SN (2020) The epidemiology and pathogenesis of coronavirus disease (COVID-19) outbreak. J Autoimmun 109:102-433

The National Institute for Occupational Safety and Health (NIOSH) (1972) Centers for disease control and prevention, criteria for a recommended standard: occupational exposure to ultraviolet radiation. DHHS (NIOSH) 73:11-29

The National Institute for Occupational Safety and Health (NIOSH) (1994) USA: NIOSH pocket guide to chemical hazards - hydrogen peroxide. https://www.cdc.gov/niosh/npg/npgd0335.html. Accessed 11 Apr 2020

The National Institute for Occupational Safety and Health (NIOSH) (1973) Ultraviolet radiation and the work environment, national institute for occupational safety and health. DHHS (NIOSH) 73:1105

Tuladhar P, Koopmans TM, Duizer E (2012) Virucidal efficacy of hydrogen peroxide vapour disinfection. J Hospit Infect 80:20

Publisher's Note Springer Nature remains neutral with regard to jurisdictional claims in published maps and institutional affiliations. 